\title{
Peningkatan Literasi Berbicara Menggunakan Media Gambar Berseri pada Siswa Kelas II SD
}

\author{
Believea Selfiyanti ${ }^{1}$, Fajar Setiawan ${ }^{2}$, Lilik Binti Mirnawati ${ }^{3}$ \\ 1, 2, 3 Program Studi Pendidikan Guru Sekolah Dasar, Universitas Muhammadiyah \\ Surabaya \\ e-mail: believea.selfiyanti-2020@fkip.um-surabaya.ac.id ${ }^{1}$, \\ fajarsetiwan@fkip.um-surabaya.ac.id ${ }^{2}$ \\ lilikbintimirnawati@fkip.um-surabaya.ac.id ${ }^{3}$
}

\begin{abstract}
Abstrak
Tujuan dari penelitian ini adalah untuk mendeskripsikan pelaksanaan pembelajaran dan peningkatan literasi keterampilan berbicara menggunakan media gambar berseri pada siswa kelas II SD. Metode dalam penelitian ini adalah PTK. Teknik pengumpulan data menggunakan teknik observasi menggunakan lembar observasi dan tes yang berupa unjuk kerja. Subjek penelitian ini adalah 26 Siswa kelas 2 SD Muhammadiyah 29 Surabaya. Data hasil penelitian menunjukkan bahwa penerapan media gambar berseri diterapkan secara daring. Kemampuan guru dalam melaksanakan pembelajaran menggunakan media gambar berseri dengan skor rata-rata pada siklus I yaitu 3,10 dan siklus II yaitu 3,53 yang dikategorikan baik. Peningkatan hasil keterampilan berbicara dapat dilihat pada hasil tes yang dilaksanakan dalam 2 siklus pembelajaran. Pada siklus I perolehan ketuntasan klasikal keterampilan berbicara yakni $74 \%$, sedangkan pada siklus II mendapatkan hasil ketuntasan klasikal $81 \%$. Berdasarkan hasil penelitian yang dilakukan selama pembelajaran dari siklus I dan siklus II setelah diberi tindakan menggunakan media gambar berseri ternyata terjadi peningkatan keterampilan berbicara siswa.
\end{abstract}

Kata kunci: gambar berseri, keterampilan berbicara, literasi

\begin{abstract}
The purpose of this study to describe the implementation of learning with serial pictures media for the second grade of elementary school students and to describe the improvement of speaking skill literacy with serial pictures media. The method used in this research is Classroom Action Research. The data collection techniques were using observation sheets and tests in the form of performance. The subjects of this study were 26 2nd grade students of SD Muhammadiyah 29 Surabaya. Data based on research results showed that the process of applying serial pictures media was applied online. The teacher's ability was to carry out serial pictures media learning with an average score in the first cycle is 3.10 and the second cycle is 3.53 which categorized as good. The improvement in speaking skill results can be seen in the carried test results out in two learning cycles. The first cycle, the acquisition of classical completeness speaking skills were $74 \%$, while in the second cycle the classical completeness results were $81 \%$. Based on the results of research conducted during learning from first cycle and second cycle, after being given action using serial pictures media, it turned out there were an increase in students' speaking skills.
\end{abstract}

Keywords : serial pictures, speaking skills, literacy

\section{PENDAHULUAN}

Pendidikan di Indonesia dapat didefinisikan sebagai usaha untuk mewujudkan suasana belajar dan proses pembelajaran agar peserta didik secara aktif mengembangkan potensi dirinya agar memiliki segala keterampilan dalam aspek kehidupan yang diperlukan untuk dirinya, masyarakat, bangsa dan negara. Pendidikan adalah pembelajaran 
pengetahuan, keterampilan, dan kebiasaan sekelompok orang yang diturunkan dari satu generasi ke generasi berikutnya melalui pengajaran, pelatihan atau penelitian (Sriwilujeng, 2017) . Dalam membelajarkan anak di sekolah membutuhkan suatu acuan yang dapat dijadikan landasan dalam pendidikan. Selain itu, kita sebagai guru pun hendaknya mengetahui ilmu dan cara mengajar yang baik, terutama pada anak sekolah dasar. Dalam pendidikan sekolah dasar, banyak mata pelajaran yang dapat menunjang ilmu pengetahuan dan pemahaman siswa, salah satunya adalah mata pelajaran Bahasa Indonesia bahwa tujuan pembelajaran Bahasa Indonesia pada sekolah dasar yaitu untuk meningkatkan kemampuan berkomunikasi siswa dalam berbahasa Indonesia melalui keterampilan baik secara lisan ataupun tulis (Fransiska, 2020). Pembelajaran Bahasa Indonesia sendiri pada dasarnya mengajarkan anak supaya memiliki kemampuan literasi yang baik dan benar.

Sebagaimana yang telah kita ketahui bahwa secara sederhana literasi diartikan sebagai sebuah kemampuan membaca dan menulis. Namun dalam abad ke-21 ini, literasi mengalami perluasan makna yang lebih dari sekedar mampu membaca dan menulis. Keterampilan literasi yang baik akan membuka jalan kepada keterampilan berbahasa lainnya, seperti menyimak, berbicara, berpikir kritis, kreatif, dan inovatif. Farihatin mengemukakan bahwa kemampuan literasi dasar memiliki peran penting dalam kehidupan seseorang untuk kesuksesan akademiknya (Kharizmi, 2015). Alternatif yang dapat diterapkan guru dalam membudayakan literasi di sekolah dasar adalah melalui program 6M (mengamati, mencipta, menginformasikan, meng-apresiasi, membukukan, memamerkan) (Akbar, 2017). Tahap menginformasikan merupakan tahap yang penting. Tahap ini dapat melatih siswa belajar melatih kemampuan berbicara serta melatih berani tampil dihadapan siswa lainnya dan mempresentasikan karyanya di depan kelas. Oleh karenanya, kemampuan berbicara merupakan dasar yang paling utama dari pengajara bahasa karena merupakan mode ekspresi yang digunakan, kemampuan pertama yang dipelajari anak-anak serta tipe kemampuan berbahasa yang paling umum dipakai (Mirnawati \& Pribowo, 2017).

Namun faktanya, dalam proses pembelajaran peserta didik banyak yang mengalami kesulitan belajar, salah satunya adalah kesulitan dalam keterampilan berbicara. Berdasarkan hasil refleksi peneliti selama mengajar di kelas II SD Muhammadiyah 29 Surabaya, diketahui bahwa keterampilan berbicara siswa masih sangat kurang. Masih banyak siswa yang sangat kurang berani berbicara di depan kelas. Misalnya saat bertanya, menjawab pertanyaan, bercerita, bahkan mengemukakan pendapat di depan kelas. Siswa sering kali menjawab pertanyaan guru dengan berbicara yang tersendat-sendat atau tidak lancar. Bahkan saat guru bertanya, siswa dengan lama sekali menjawab pertanyaan tersebut dikarenakan mereka takut jawabannya salah. Kondisi tersebut diperparah dari temuan peneliti dimana ketika guru bertanya atau meminta siswa secara individu untuk bercerita secara lisan di depan kelas, jika di persentasekan sebanyak 40\% yaitu dari 25 siswa hanya terdapat 10 siswa yang mampu bercerita dengan baik.

Siswa yang mengikuti kelas Bahasa Indonesia boleh jadi sudah menguasai keterampilan berbicara di dalam Bahasa Indonesia, tetapi keterampilan yang dikuasai pada keterampilan berbicara dalam kelompok kecil atau satu lawan satu. Bagi banyak siswa, kegiatan berbicara di depan kelas meskipun hanya mengajukan pertanyaan, merupakan kegiatan yang sulit dilakukan. Hal itu selaras dengan yang disampaikan oleh Dewantara bahwa mempunyai keterampilan berbicara tidaklah semudah yang dibayangkan karena banyak orang yang pandai menulis, tetapi ketika diminta menyampaikan tulisannya dalam bentuk lisan hasilnya tidak begitu bagus (Dewantara et al., 2012).

Begitu pula sebaliknya, banyak orang yang dapat berbicara dengan baik, tetapi menemui kendala ketika diminta menuliskan idenya. Padahal tujuan berbicara adalah melatih siswa mengemukakan isi hatinya secara lisan dengan kalimat yang teratur dan baik, memperbesar dorongan batin akan melahirkan isi hatinya, memupuk keberanian berbicara pada siswa, menambah pembendaharaan bahasa siswa, dan memberikan kesempatan pada siswa untuk menyatakan dirinya (Fransiska, 2020). Kesulitan berbicara yang masih banyak dialami oleh siswa kelas rendah dikarenakan siswa kelas rendah masih merasa minder dan takut untuk berbicara (Ferina et al., 2020). 
Berdasarkan apa yang dikemukakan di atas, maka perlu dicari alternatif penyelesaian sebagai upaya untuk meningkatkan kemampuan berbicara siswa. Salah satu upaya yang bisa digunakan untuk mengatasi masalah tersebut adalah guru harus kreatif dalam melaksanakan proses pembelajaran. Hal ini dapat dilakukan dengan berbagai cara, salah satunya adalah dengan menggunakan media pembelajaran yang sesuai dengan tujuan pembelajaran dan respon yang diharapkan dikuasai siswa setelah pembelajaran berlangsung. Media yang dapat digunakan antara lain audio visual, boneka tangan, gambar, dll. Pemilihan dan penggunaan media yang tepat tentunya akan memaksimalkan keterampilan berbicara siswa sesuai tujuan yang diharapkan. Peneliti pun berencana menggunakan gambar berseri sebagai media pembelajaran. Menurut Arsyad, media gambar seri merupakan media pembelajaran berupa gambar yang mengandung cerita dengan beberapa urutan sehingga antara gambar yang satu dengan gambar yang lainnya membentuk satu kesatuan yang menggambarkan peristiwa dalam bentuk cerita tersusun (Aprinawati, 2017). Penggunaan media gambar seri dapat mengem $\neg$ bangkan potensi perkembangan berbicara anak yaitu dengan cara anak dapat menyampaikan pesan terdiri dari dua atau tiga kata dan dapat memunculkan kalimat-kalimat yang lebih rumit.

Keuntungan dalam penggunaan media gambar menunjukkan bahwa media gambar memiliki dampak positif bagi anak (Muna et al., 2019). Selain metode maupun model pembelajaran, guru merasa bahwa digunakannya media pembelajaran untuk mendukung pelaksanaan pembelajaran dapat membantu mencapai keberhasilan belajar siswa. Pada penelitian ini perbedaannya adalah subjek dan lokasi yaitu pada siswa kelas IV SD Muhammadiyah I Malang.

Adapun dalam penelitian lain menunjukkan bahwa pembelajaran berbicara dengan menggunakan media gambar mendapatkan hasil yang cukup memuaskan, dari yang asalnya tidak bisa berbicara menjadi lebih lancar dan berani untuk bercerita. Keseluruhan peralihan adanya peningkatan keberhasilan yang awalnya dari $10,34 \%$ meningkat menjadi $51,72 \%$. Berdasarkan temuan dan pembahasan hasil penelitian dapat disimpulkan bahwa pembelajaran Bahasa Indonesia dengan menggunakan media gambar dapat meningkatkan kemampuan berbicara siswa kelas IV SD Negeri 2 Sukamaju Kota Tasikmalaya pada tahun pelajaran 2019/2020 (Damanix, 2021).

Berdasarkan kajian penelitian relevan di atas, pemilihan dan penggunaan media yang tepat dapat menarik perhatian siswa dalam pembelajaran dan dapat membantu mengatasi permasalahan. Maka dari itu, peneliti tertarik untuk melakukan penelitian dengan judul "Peningkatan Literasi Dasar Keterampilan Berbicara Menggunakan Media Gambar Seri pada Siswa Kelas II SD Muhammadiyah 29 Surabaya”. Adapun penelitian ini bertujuan untuk mendeskripsikan proses pelaksanaan pembelajaran menggunakan media gambar seri pada Siswa Kelas II SD Muhammadiyah 29 Surabaya dan mendeskripsikan peningkatan literasi dasar keterampilan berbicara menggunakan media gambar seri pada siswa kelas II SD Muhammadiyah 29 Surabaya.

\section{METODE PENELITIAN}

Berisi bagaimana data dikumpulkan, sumber data dan cara analisis data Penelitian ini dilakukan di SD Muhammadiyah 29 Five Days School, Kecamatan Sukomanunggal, Kota Surabaya. Pengambilan data direncakanan pada bulan November hingga Desember 2021. Adapun subjek penelitian ini adalah siswa kelas II-A yang berjumlah 26 siswa di tahun ajaran $2021 / 2022$.

Jenis penelitian yang dilakukan merupakan penelitian tindakan kelas (PTK). PTK merupakan penelitian yang berorientasi untuk memperbaiki suatu keadaan atau permasalahan praktis yang dihadapi termasuk dalam konteks pendidikan khususnya pembelajaran di kelas yang bertujuan untuk meningkatkan mutu pendidikan (Setiawan, 2017). Adapun Arikunto dkk. (2014) mengemukakan bahwa pada setiap siklus tindakan yang dilaksanakan terdiri atas empat tahapan, yaitu perencanaan, pelaksanaan, pengamatan dan refleksi. Hal ini merupakan salah satu ciri penelitian tindakan kelas. Adapun siklus PTK dapat dilihat pada gambar di bawah ini. 


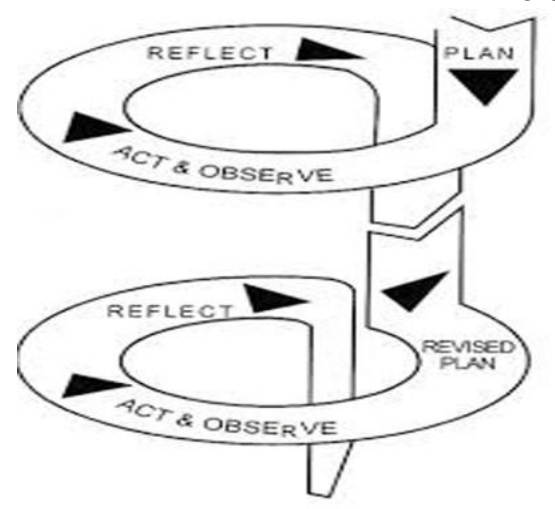

\section{Gambar 1. Siklus PTK (Prihantoro \& Hidayat, 2019)}

Tahap perencanaan yaitu menganalisis kurikulum untuk mengetahui standar kompetensi, kompetensi dasar, menyusun rancangan pembelajaran (RPP), mempersiapkan materi pembelajaran, menentukan metode/strategi pembelajaran, menyusun perangkat penilaian, menentukan teknik penelitian, dan mengalokasikan waktu. Pada tahap ini peneliti menentukan guru kolaborator dari rekan sejawat sendiri atas nama Miko Fitri Ana, sedangkan peneliti bertindak sebagai pengamat.

Tahap pelaksanaan tindakan yaitu tahap siklus I peneliti menggunakan gambar yang berhubungan dengan ruangan yang bersih yang disajikan dalam bentuk power point. Pembelajaran yang dilakukan oleh guru dalam mengajar selama pembelajaran berlangsung menggunakan sistem daring (dalam jaringan) melalui zoom dan sesuai dengan RPP serta langkah-langkah yang telah dirancang yang akan dilakukan dalam proses pembelajaran.

Tahap observasi pada saat pelaksanaan tindakan siklus 1 dilaksanakan oleh pengamat selama pembelajaran berlangsung. Peneliti yang bertindak sebagai observer melakukan pengamatan dan mencatat perkembangan-perkembangan yang terjadi baik pada siswa ataupun pada guru kolaborator.

Tahap refleksi yaitu berupa uraian tentang prosedur analisis terhadap hasil penelitian yang berkaitan dengan proses dan dampak tindakan perbaikan yang dilaksanakan dan rencana bagi tindakan selanjutnya.

Teknik pengumpulan data yang digunakan ada dua teknik, yaitu observasi dan tes yang berupa unjuk kerja. Observasi adalah metode atau cara menghimpun data yang dilakukan dengan mengadaan pengamatan atau pencatatan secara sistematis terhadap keadaan yang sedang dijadikan sebagai sasaran pengamatan (Mania, 2008). Dalam penelitian ini, observasi dilakukan untuk mendapatkan data pengamatan upaya guru dalam menerapkan pembelajaran menggunakan media gambar berseri untuk mengatahui keterampilan berbicara siswa menggunakan instrumen lembar observasi.

Adapun tes merupakan alat untuk mengevaluasi hasil belajar yang digunakan dalam rangka pengukuran dan penilaian di bidang pendidikan (Kadir, 2015). Dalam penelitian ini, tes digunakan untuk mendapatkan data tentang peningkatan keterampilan berbicara siswa untuk mengetahui sampai sejauh mana keberhasilan yang dicapai menggunakan instrumen lembar tes unjuk kerja keterampilan berbicara.

Teknik analisis data yang digunakan adalah perhitungan keterlaksanaan pembelajaran menggunakan media gambar seri dan perhitungan peningkatan literasi dasar keterampilan berbicara menggunakan media gambar seri. Adapun rumusnya adalah sebagai berikut.

Analisis data keterlaksanaan pembelajaran menurut Anas (Ramadi, 2013).

Keterangan:

$$
M x=\frac{\sum x}{N}
$$

$\mathrm{Mx}$ = rata-rata (mean) keterlaksanaan pembelajaran

$\Sigma x \quad=$ jumlah semua nilai siswa

$\mathrm{N} \quad=$ jumlah siswa 
Analisis data peningkatan keterampilan berbicara siswa menurut Anas (Ramadi, 2013).

Keterangan:

$$
P=\frac{f}{N} \times 100 \%
$$

$\mathrm{P} \quad=$ Persentase

$\mathrm{f} \quad=$ frekuensi yang sedang dicari persentasenya

$\mathrm{N} \quad=$ jumlah frekuensi/banyaknya skor maksimal

Dalam implementasinya PTK ini dilaksanakan minimal selama 2 siklus atau ketika indikator keberhasilan penelitian sudah terpenuhi. Adapun indikator keberhasilan penelitian ini adalah (1) pelaksanaan pembelajaran dikatakan berhasil jika mencapai persentase minimal $80 \%$, (2) ketuntasan belajar secara klasikal jika mencapai persentase minimal $75 \%$.

\section{HASIL DAN PEMBAHASAN}

Peneliti terlebih dahulu melakukan observasi awal yang bertujuan untuk memperoleh data permasalahan pembelajaran yang akan digunakan sebagai pedoman dalam melakukan perencanaan di siklus I.

\section{Siklus I}

Tujuan dilaksanakannya siklus I adalah untuk menindaklanjuti hasil dari refleksi pada pra siklus untuk mengatasi kesulitan siswa menggunakan media gambar berseri yang diharapkan akan membantu memotivasi timbulnya gagasan siswa dalam bercerita dan menambah kosakata Bahasa Indonesia untuk meningkatkan kemampuan berbicara siswa. Atas dasar analisis observasi awal, langkah berikutnya yang dilakukan adalah mengadakan diskusi dengan teman sejawat sebagai guru kolaborator.

\section{a. Perencanaan}

Hal-hal yang dilakukan dalam tahap perencanaan adalah membahas waktu penelitian siklus I akan dilaksanakan serta penjelasan umum dari peneliti kepada guru kolaborator mengenai pembelajaran membahas penyusunan RPP, mulai menetap dan memilih jenis gambar yang sesuai dengan siswa kelas II yaitu menggunakan beberapa buku sumber, situasi dan kondisi kelas yang akan digunakan serta mempersiapkan instrumen-instrumen sebagai alat pengumpul data. Rencana pengajaran pada siklus pertama ini terdiri dari satu kali pertemuan dengan alokasi waktu yaitu $2 \times 35$ menit yang berpedoman pada kurikulum.

b. Pelaksanaan Tindakan

Pelaksanaan proses pembelajaran pada siklus I ini dilaksanakan hari Senin, 6 Desember 2021 selama 70 menit atau 2 jam pelajaran. Satu jam yang pertama dilakukan untuk 13 siswa dan jam yang kedua dilakukan untuk 13 siswa berikutnya. Proses pelaksanaan pembelajaran ini dengan cara individual, hal ini dimungkinkan lebih efektif untuk mengkondisikan siswanya dalam pembelajaran daring. Pelaksanaan guru kolaborator yaitu Miko Fitri Ana. Langkah pertama dalam pembelajaran guru membuka pelajaran (apersepsi) lalu menjelaskan langkah-langkah dasar dalam bercerita dan menjelaskan pula hal-hal yang harus diperhatikan dalam menggunakan media gambar. Langkah selanjutnya melihat situasi dan kondisi kelas sudah tampak tertib, lalu guru memperlihatkan gambar seri yang ada pada slide power point untuk diamati dan diceritakan isinya. Kemudian guru menjelaskan kegiatan yang harus dilaksankaan siswa dengan gambarnya.

Hasil pengamatan pada siklus pertama siswa ribut dan bertanya kepada guru karena tidak paham tentang tugas yang harus dikerjakan, guru kembali menjelaskan pertanyaanpertanyaan dari siswa. Rupanya siswa ramai dan bertanya kesulitan yang dialami. Ketika ditunjuk dan disuruh bercerita secara individu siswa merasa keberatan yang ditandai dengan heningnya aktivitas saat pembelajaran. Lalu guru memotivasi siswa agar berani untuk bercerita. Ada salah seorang siswa yang meminta agar ditulis dulu ceritanya baru dibacakan 
di depan teman-temannya. Sebagian siswa ada yang tidak peduli, mereka hanya membicarakan tentang gambar bukan menyusun cerita. Guru memberikan nilai pada lembar penilaian dan langsung mengomentari hasil presentasi siswa. Siswa diberi kesempatan bertanya mengenai materi yang belum jelas, guru memberikan penghargaan kepada siswa berupa tepuk tangan kepada siswa yang berani dan mampu menceritakan gambar dengan baik. Pada kegiatan penutup, siswa bersama guru menyimpulkan materi yang telah dipelajari, lalu melakukan refleksi terhadap proses pembelajaran yang telah dilakukan.

c. Observasi

Hasil observasi terhadap kemampuan guru dalam pelaksanaan pembelajaran dapat disajikan dalam Tabel berikut ini.

Tabel 1. Hasil Observasi Kemampuan Guru Mengajar Siklus I
\begin{tabular}{clc} 
No & Aspek yang diamati & Skor \\
\hline 1 & Membuka & 3.5 \\
& pembelajaran & \\
2 & Kegiatan inti & 2.8 \\
3 & Penutup & 3 \\
\hline Skor total & $\mathbf{9 . 3}$ \\
\hline Skor rata-rata & $\mathbf{3 . 1 0}$ \\
\hline
\end{tabular}

Keterangan: 4 = Sangat Baik; 3 = Baik; 2 = Cukup baik; 1 = Kurang

Pembahasan : Dari hasil observasi tersebut, diperoleh data hasil kemampuan guru dalam mengajar menggunakan media gambar pada pembelajaran berbicara memiliki skor rata-rata 3.10 yang dikategorikan baik.

\begin{tabular}{|c|c|c|c|}
\hline No & Aspek yang diamati & Skor & Rata-rata \\
\hline 1 & Keberanian siswa saat berbicara & 81 & 3.12 \\
\hline 2 & Lafal dan intonasi dalam berbicara & 73 & 2.81 \\
\hline 3 & Kelancaran siswa dalam berbicara & 67 & 2.58 \\
\hline 4 & Kekayaan kosakata & 82 & 3.15 \\
\hline 5 & Mengungkap ide cerita & 71 & 2.73 \\
\hline \multirow[t]{4}{*}{6} & Kemampuan siswa menceritakan secara urut dan jelas & 87 & 3.35 \\
\hline & Jumlah & 461 & 17.73 \\
\hline & Rata-rata & & 2.96 \\
\hline & Ketuntasan klasikal & & $74 \%$ \\
\hline
\end{tabular}

\section{Pembahasan}

Jumlah skor yang muncul pada indikator keberanian siswa saat berbicara adalah $m x=\frac{81}{26}=3,12$. Jumlah skor yang muncul pada indikator lafal dan intonasi siswa dalam berbicara yaitu $m x=\frac{73}{26}=2,81$. Jumlah skor yang muncul pada indikator kelancaran siswa saat berbicara adalah $m x=\frac{67}{26}=2,58$. Jumlah skor yang muncul pada indikator kekayaan kosakata yaitu $m x=\frac{82}{26}=3,15$. Jumlah skor yang muncul pada indikator mengungkap ide cerita atau gagasan yaitu $m x=\frac{71}{26}=2,73$. Jumlah skor yang muncul pada indikator kemampuan siswa menceritakan secara urut dan jelas yaitu $m x=\frac{87}{26}=3,35$. Maka, rata-rata yang diperoleh pada keterampilan berbicara pada siklus I adala $m x=\frac{17,74}{6}=2,96$

d. Refleksi

Refleksi yang dilakukan setelah melakukan tindakan pada siklus I dari data yang diperoleh selama observasi siklus I saat pembelajaran Bahasa Indonesia berlangsung pada siswa kelas IIA SD Muhammadiyah 29 Surabaya. Diadakan refleksi oleh guru kolaborator dan peneliti mengenai hasil pengamatan pada siklus pertama. Adapun kelebihannya yaitu 
siswa terlihat lebih antusias dalam pelaksanaan pembelajaran menggunakan media gambar, sehingga dalam pengelolaan kelas oleh guru bisa lebih maksimal. Tetapi ada beberapa catatan hasil diskusi yaitu :

1. Situasi belum terkoordinasi dengan baik, hal ini terlihat pada saat proses pembelajaran berlangsung ada siswa yang masih ngobrol dengan temannya sehingga terjadi keramaian saat pembelajaran zoom.

2. Dalam pelaksanaan bercerita secara individu, masih banyak siswa yang kesulitan untuk bercerita sehingga mereka minta untuk dibimbing kata demi kata untuk menjadi kalimat yang sederhana.

3. Keberanian siswa ketika diminta menceritakan secara individu masih kurang sehingga mempengaruhi aspek kebahasaan yang lain seperti lafal dan intonasi, suara terdengar pelan di karenakan takut salah.

Dari ketiga hal diatas perlu mendapat perhatian pada siklus berikutnya, bertujuan agar kemampuan berbicara siswa lebih optimal.

\section{Siklus II}

Tujuan dari pelaksanaan siklus kedua adalah untuk meningkatkan kemampuan berbicara siswa lebih optimal dan siswanya lebih aktif mengikuti pembelajaran berbicara agar memperoleh hasil yang memuaskan.

a. Perencanaan

Hal-hal yang dilakukan dalam tahap perencanaan yaitu, membahas mengenai hasil refleksi pada siklus I dan menyusun RPP yang mengacu pada tindakan yang akan diterapkan dalam penelitian tindakan pada siklus II, menyiapkan media gambar sesuai dengan tema yang telah disepakati bersama guru kolaborator dan menyiapkan alat pengumpul data.

b. Pelaksanaan Tindakan

Pelaksanaan proses pembelajaran pada siklus II ini dilaksanakan hari Selasa, 7 Desember 2021 selama 70 menit atau 2 jam pelajaran seperti pada siklus I. Siswa yang hadir berjumlah 26 orang. Langkah pertama dalam pembelajaran guru membuka pelajaran (apersepsi), memberikan informasi materi dan tujuan pembelajaran dan terakhir mengkondisikan kelas. Lalu menjelaskan langkah-langkah dasar dalam bercerita dan menjelaskan pula hal-hal yang harus diperhatikan dalam menggunakan media gambar seperti pada siklus I. Kemudian guru menjelaskan kegiatan yang harus dilaksankan siswa dengan gambarnya.

Hasil pengamatan pada siklus kedua siswa ribut tetapi mereka tampak senang karena siswa sudah paham apa yang harus dilakukan. Ketika guru meminta siswa yang mau bercerita di depan teman-temannya dengan serempak siswa menjawab "saya". Ternyata mereka bersemangat sekali. Saat siswa mulai bercerita, teman-temannya mendengarkan dengan seksama dan mereka bertepuk tangan ketika ceritanya selesai walaupun cerita tersebut hanya beberapa kalimat saja yang diungkapkannya. Siswa melanjutkan kegiatan bercerita secara bergiliran. Guru mengamati siswa dan memberikan penilaian pada lembar penilaian dan langsung mengomentari hasil presentasi siswa. Siswa diberi kesempatan bertanya mengenai materi yang belum jelas, guru memberikan penghargaan kepada siswa berupa tepuk tangan kepada siswa yang berani dan mampu menceritakan gambar dengan baik. Pada kegiatan penutup, siswa bersama guru menyimpulkan materi yang telah dipelajari, memberikan penguatan dan pengayaan tentang cerita yang disampaikan oleh semua siswa secara garis besar.

c. Observasi

Hasil observasi terhadap kemampuan guru dalam pelaksanaan pembelajaran dapat disajikan dalam Tabel berikut ini. 


Tabel 3. Hasil Observasi Kemampuan Guru Menga
\begin{tabular}{clc} 
No & Aspek yang diamati & Skor \\
\hline 1 & Membuka pembelajaran & 3.5 \\
\hline 2 & Kegiatan inti & 3.6 \\
\hline 3 & Penutup & 3,5 \\
\hline & Skor total & $\mathbf{1 0 , 6}$ \\
\hline & Skor rata-rata & $\mathbf{3 . 5 3}$ \\
\hline
\end{tabular}

Keterangan: 4 = Sangat Baik; 3 = Baik; 2 = Cukup baik; 1 = Kurang

Pembahasan : Dari hasil observasi tersebut, diperoleh data hasil kemampuan guru dalam mengajar menggunakan media gambar pada pembelajaran berbicara memiliki skor rata-rata 3.53 yang dikategorikan baik.

\begin{tabular}{|c|c|c|c|}
\hline No & Aspek yang diamati & Skor & Rata-rata \\
\hline 1 & Keberanian siswa saat berbicara & 86 & 3,31 \\
\hline 2 & Lafal dan intonasi dalam berbicara & 80 & 3,08 \\
\hline 3 & Kelancaran siswa dalam berbicara & 79 & 3,04 \\
\hline 4 & Kekayaan kosakata & 81 & 3,12 \\
\hline 5 & Mengungkap ide cerita & 83 & 3,19 \\
\hline \multirow[t]{4}{*}{6} & Kemampuan siswa menceritakan secara urut dan jelas & 94 & 3.62 \\
\hline & Jumlah & 503 & 19,35 \\
\hline & Rata-rata & & 3,22 \\
\hline & Ketuntasan klasikal & & $81 \%$ \\
\hline
\end{tabular}

\section{Pembahasan :}

Jumlah skor yang muncul pada indikator keberanian siswa saat berbicara adalah $m x=\frac{86}{26}=3,31$. Jumlah skor yang muncul pada indikator lafal dan intonasi siswa dalam berbicara yaitu $m x=\frac{80}{26}=3.08$. Jumlah skor yang muncul pada indikator kelancaran siswa saat berbicara adalah $m x=\frac{79}{26}=3.04$. Jumlah skor yang muncul pada indikator kekayaan kosakata yaitu $m x=\frac{81}{26}=3,12$. Jumlah skor yang muncul pada indikator mengungkap ide cerita atau gagasan yaitu $m x=\frac{83}{26}=3.19$. Jumlah skor yang muncul pada indikator kemampuan siswa menceritakan secara urut dan jelas yaitu $m x=\frac{94}{26}=3,62$. Maka, rata-rata yang diperoleh pada keterampilan berbicara pada siklus I adalah $m x=\frac{19,35}{6}=3,22$.

d. Refleksi

Refleksi yang dilakukan setelah melakukan tindakan pada siklus II dari data yang diperoleh selama observasi siklus II saat pembelajaran Bahasa Indonesia berlangsung pada siswa kelas IIA SD Muhammadiyah 29 Surabaya. Diadakan refleksi oleh guru kolaborator dan peneliti mengenai hasil pengamatan pada siklus pertama. Adapun kelebihan-kelebihan yang terjadi pada pelaksanaan siklus II antara lain guru menguasai materi pelajaran dan hampir terampil menerapkan menggunakan media gambar, siswa sudah terbiasa dengan menggunakan media gambar, keaktifan siswa dalam berbicara dan bercerita sudah menunjukkan peningkatan yang cukup baik dari pembelajaran yang telah dilaksanakan. Kekurangan yang terjadi pada pembelajaran siklus II antara lain masih terdapat beberapa siswa yang belum berani untuk berbicara di depan.

Setelah hasil refleksi siklus II dianalisis, maka peneliti dan guru kolaborator menyimpulkan jika penelitian ini dinyatakan selesai dan tidak dilanjutkan ke siklus berikutnya karena pelaksanaan pembelajaran dikatakan mencapai persentase minimal $80 \%$, dan ketuntasan belajar secara klasikal mencapai persentase minimal $75 \%$. 


\section{Pembahasan}

Berdasarkan hasil penelitian yang dilakukan selama pembelajaran dari siklus I dan siklus II setelah diberi tindakan menggunakan media gambar berseri ternyata terjadi peningkatan keterampilan berbicara siswa. Hal tersebut sejalan dengan yang dikemukakan oleh Setiawan (2017) bahwa dengan menggunakan media pembelajaran, proses pembelajaran dapat lebih menarik serta kualitas pembelajaran dapat ditingkatkan.

Saat dilakukan tindakan pada setiap siklus, siswa terlihat antusias ketika guru menggunakan media pembelajaran. Hal ini sangat memungkinkan, mengingat dengan gambar berseri siswa akan lebih mudah berimajinasi dan mendapat gambaran nyata terhadap suatu kejadian. Guru pun bisa lebih menguasai materi dan terampil dalam menggunakan media pembelajaran.

Hasil pengamatan selama proses penelitian mendapatkan hasil pada diagram berikut.

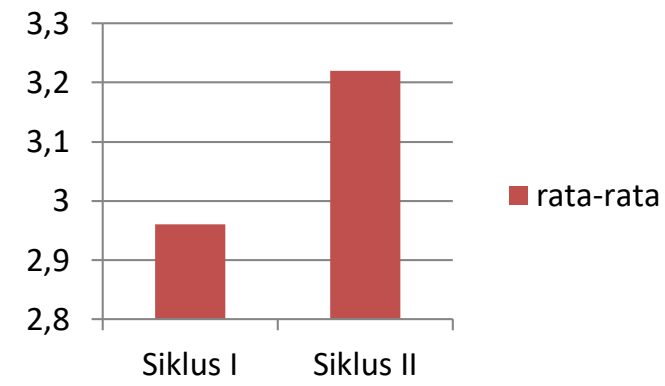

Gambar 2. Diagram batang rata-rata keterlaksanaan pembelajaran

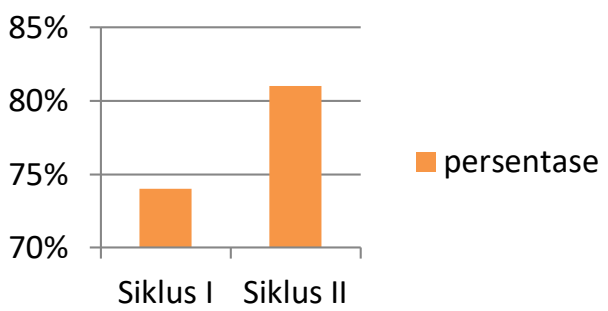

\section{Gambar 3. Diagram batang persentase ketuntasan klasikal peningkatan keterampilan} berbicara

\section{SIMPULAN}

Berdasarkan penelitian yang telah dilakukan pada siswa kelas IIA SD Muhammadiyah 29 Surabaya, dapat disimpulkan bahwa penggunaan media gambar dalam pembelajaran bahasa dan sastra Indonesia ternyata dapat meningkatkan kemampuan guru dalam melaksanakan pembelajaran dan keterampilan berbicara siswa dalam pembelajaran. Kemampuan guru dalam melaksanakan pembelajaran menggunakan media gambar yaitu pada siklus I dengan skor rata-rata 3,10 dan siklus II dengan skor rata-rata 3,53 atau terjadi peningkatan sekitar 0,43 .

Dengan menggunakan media gambar dalam pembelajaran bahasa Indonesia, ternyata dapat meningkatkan keterampilan berbicara siswa. Pada siklus I ketuntasan klasikal sebesar $74 \%$ sedangkan pada siklus II ketuntasan klasikal sebesar $81 \%$.

\section{DAFTAR PUSTAKA}

Akbar, A. (2017). Membudayakan Literasi Dengan Program 6M Di Sekolah Dasar. Jurnal Pendidikan Sekolah Dasar, 3(1), 42.

Aprinawati, I. (2017). Penggunaan Media Gambar Seri Untuk Meningkatkan Kemampuan Berbicara Anak Usia Dini. Jurnal Obsesi : Jurnal Pendidikan Anak Usia Dini, 1(1), 72. 
Damanix, C. (2021). Peningkatan Kemampuan Berbicara Siswa Kelas IV SD Negeri 2 Sukamaju Kota Tasikmalaya Melalui Penggunaan Media Gambar. Jurnal Wahana Pendidikan, 8(1), 27.

Dewantara, I. P. M. (2012). Identifikasi Faktor Penyebab Kesulitan Belajar Keterampilan Berbicara Siswa Kelas VII E SMPN 5 Negara Dan Strategi Guru Untuk Mengatasinya. Jurnal Pendidikan Bahasa Indonesia. 1-15.

Ferina, O. M., Ardhyntama, V., \& Fath, A. M. A (2020). Analisis Faktor Penyebab Kesulitan Berbicara Siswa Kelas 3 SD Negeri 1 Hadiluwih Tahun Ajaran 2019/2020. Repository STKIP PGRI Pacitan.

Fransiska, E. (2020). Penggunaan Gambar Seri Untuk Meningkatkan Keterampilan Berbicara Siswa Kelas 1 Sdi Onekore 6. Jurnal Literasi: Pendidikan Dan Humaniora, 5(3), 41-52.

Kadir, A. (2015). Menyusun Dan Menganalisis Tes Hasil Belajar. Abdul Kadir. Al-Ta'dib, 8(2), 70-81.

Kharizmi, M. (2015). Kesulitan Siswa Sekolah Dasar Dalam Meningkatkan Kemampuan Literasi. Jupendas: Jurnal Pendidikan Dasar, 2(2), 11-21.

Mania, S. (2008). Observasi Sebagai Alat Evaluasi Dalam Dunia Pendidikan Dan Pengajaran. Lentera Pendidikan: Jurnal IImu Tarbiyah Dan Keguruan, 11(2), 220233.

Mirnawati, L. B., \& Pribowo, F. S. P. (2017). Penerapan Model Pembelajaran Savi Untuk Meningkatkan Kemampuan Berbicara Mahasiswa Pgsd Fkip Universitas Muhammadiyah Surabaya. ELSE (Elementary School Education Journal), 1, 144152.

Muna, E. N., Degeng, I. N. S., \& Hanurawan, F. (2019). Upaya Peningkatan Keterampilan Berbicara Menggunakan Media Gambar Siswa Kelas IV SD. Jurnal Pendidikan: Teori, Penelitian, Dan Pengembangan, 4(11), 1557.

Prihantoro, A., \& Hidayat, F. (2019). Melakukan Penelitian Tindakan Kelas. Ulumuddin: Jurnal IImu-IImu Keislaman, 9(1), 49-60.

Ramadi, R., (2013). Meningkatkan Keterampilan Berbicara Menggunakan Media Gambar Pada Siswa Kelas V Sekolah Dasar. Jurnal Pendidikan Dan Pembelajaran Khatulistiwa, 2(2).

Setiawan, F. (2017). Upaya Meningkatkan Keterampilan Menulis Karangan Siswa Kelas Iv Sekolah Dasar Dengan Menggunakan Media Gambar Berseri. ELSE (Elementary School Education Journal), 1(1), 26-37.

Sriwilujeng, D. (2017). Panduan Implementasi Penguatan Pendidikan Karakter. Esensi Erlangga Group. 